\title{
Salafism in Nigeria: Islam, Preaching, and Politics
}

\author{
Alexander Thurston
}

New York: Cambridge University Press, 2016. 300 pages.

The global spread of Salafism, though it began in the 1960s and 1970s, only started to attract significant attention from scholars and analysts outside of Islamic studies as well as journalists, politicians, and the general public following the September 11, 2001 terrorist attacks perpetrated by Al-Qaeda Central. After the attacks, Salafism-or, as it was pejoratively labeled by its critics inside and outside of the Islamic tradition, "Wahhabism"-was accused of being the ideological basis of all expressions of Sunni militancy from North America and Europe to West and East Africa, the Arab world, and into Asia. According to this narrative, Usama bin Laden, Ayman al-Zawahiri, Abu Bakr al-Baghdadi, and other Sunni jihadis were merely putting into action the commands of medieval 'ulama such as Ibn Taymiyya, the eighteenth century Najdi Hanbali Muhammad ibn 'Abd al-Wahhab, and modern revolutionary ideologues like Sayyid Qutb and 'Abdullah 'Azzam. To eradicate terrorism, you must eliminate or neuter Salafism, say its critics. 
The reality, of course, is far more complex than this simplistic narrative purports. Salafism, though its adherents share the same core set of creedal beliefs and methodological approaches toward the interpretation of the Qur'an and hadith and Sunni legal canon, comes in many forms, from the scholastic and hierarchical Salafism of the 'ulama in Saudi Arabia and other Muslim majority countries to the decentralized, self-described Salafi groups in Europe and North America who cluster around a single charismatic preacher who often has limited formal religious education. What unifies these different expressions of Salafism is a core canon of religious and legal texts and set of scholars who are widely respected and referenced in Salafi circles. Thurston grounds his fieldwork and text-based analysis of Salafism in Nigeria, Africa's most populous country and home to one of the world's largest single Muslim national populations, through the lens of this canon, which he defines as a "communally negotiated set of texts that is governed by rules of interpretation and appropriation" (1). He argues further that in the history of Nigerian Salafism, one can trace the major stages that the global Salafi movement has navigated as it spread from the Arab Middle East to what are erroneously often seen as "peripheral" areas of the Islamic world, Africa and parts of Asia. The book is based on extensive fieldwork in Nigeria including interviews with key Nigerian Salafi scholars and other leading figures as well as a wide range of textual primary sources including British and Nigerian archival documents, international and national news media reports, leaked US embassy cables, and a significant number of religious lectures and sermons and writings by Nigerian Salafis in Arabic and Hausa.

In Chapter One, Thurston argues that the Salafi canon gives individual and groups of Salafis a sense of identity and membership in a unique and, to them, superior religious community that is linked closely to their understanding and reading of sacred history and the revered figures of the Prophet Muhammad and the Șahāba. Salafism as an intellectual current, theology, and methodological approach is transmitted through this canon which serves not only as a vehicle for proselytization but also a rulebook through which the boundaries of what is and is not "Salafism" are determined by its adherents and leading authorities. The book's analytical framework and approach toward understanding Salafism, which rests on seeing it as a textual tradition, runs counter to the popular but problematic tendency in much of the existing discussion and even scholarly literature on Salafism that defines it as a literalist, one-dimensional, and puritanical creed with a singular focus on the Qur'an and hadith canon. Salafis, 
Thurston argues, do not simply derive religious and legal rulings in linear fashion from the Qur'an and Prophetic Sunna but rather engage in a coherent and uniform process of aligning today's Salafi community with a set of normative practices and beliefs laid out by key Salafi scholars from the recent past.

Thurston divides the emergence of a distinct "Salafi" current within Sunnis into two phases. The first stretches from 1880 to 1950, as Sunni scholars from around the Muslim-majority world whose approaches shared a common hadith-centered methodology came into closer contact. The second is from the 1960s through the present, as key Salafi institutions (such as the Islamic University of Medina and other Saudi Salafi bodies) were founded and began attracting and (perhaps most importantly) funding and sponsoring Sunni students from countries such as Nigeria to come study in Saudi Arabia, where they were deeply embedded in the Salafi tradition before returning to their home countries where, in turn, they spread Salafism among local Muslims. Nigeria's Muslim-majority north, as with other regions such as Yemen's northern Sa'ada governorate, proved to be a fertile ground for Salafism in large part because it enabled local Muslims from more humble social backgrounds to challenge the longtime dominance of hereditary ruling families and the established religious class. In northern Nigeria the latter was and continues to be dominated by Sufi orders and their shaykhs whose long-running claim to communal leadership faced new and substantive theological and resource challenges following the return of Nigerian seminary students from Saudi Arabia's Salafi scholastic institutions in the 1990s and early 2000s.

In Chapters Two and Three, Thurston traces the history of Nigerian and other African students in Saudi Arabia, which significantly expanded following the 1961 founding of the Islamic University of Medina (which remains the preeminent Salafi seminary and university in the world) and after active outreach across the Sunni Muslim world by the Saudi government and Salafi religious elite to attract students through lucrative funding and scholarship packages. The process of developing an African Salafism was not one-dimensional or imposed from the top-down by Saudi Salafi elites, but instead saw Nigerian and other African Salafi students participate actively in shaping and theorizing Salafi $d a^{i} w a$ that took into account the specifics of each African country and Islamic religious and social environment. In Nigeria and other parts of West and East Africa, this included considering the historically dominant position of Sufi orders and popular practices such as devotion to saints and grave and shrine visitation. African 
and Saudi Salafis also forged relationships with local African partners, including powerful political figures such as Ahmadu Bello and his religious adviser Abubakar Gumi, by attracting them with the benefits of establishing ties with wealthy international Islamic organizations founded and backed by the Saudi state, including the Muslim World League.

Nigerian Salafis returning from their studies in Saudi Arabia actively promoted their Salafi canon among local Muslims, waging an aggressive proselytization campaign that sought to chip away at the dominance of traditional political and religious elites, the Sufi shaykhs. This process is covered in Chapter Four. Drawing on key sets of legal and exegetical writings by Ibn Taymiyya, Muhammad ibn 'Abd al-Wahhab, and other Salafi scholars, Nigerian Salafis sought to introduce a framework-represented by the canon-through which their students and adherents approach religious interpretation and practice. By mastering one's understanding and ability to correctly interpret scripture and the hadith, Salafis believe, one will also live a more ethical life based on a core set of "Salafi" principles that govern not only religious but also political, social, and economic life. Salafism, Thurston argues, drawing on the work of Terje Østebø on Ethiopian Salafism, becomes localized within a specific environment.

As part of their $d a^{i} w a$ campaigns, Nigerian Salafis have utilized media and new technology to debate their rivals and critics as well as to broaden their own influence over Nigerian Muslims and national society more broadly, actions analyzed in Chapter Five. Using the Internet, video and audio recorded sermons and religious lectures, books and pamphlets, and oral proselytization and preaching, Nigerian Salafis, like other Muslim activists and groups, see in media and technology an extension of the physical infrastructure provided by institutions such as mosques and religious schools. This media/cyber infrastructure is as, if not increasingly more, valuable as the control of physical space because it allows for the rapid spread of ideas beyond what would have historically been possible for local religious preachers and missionaries. Instead of preaching political revolution, Nigerian Salafi activists sought to win greater access to the media including radio airtime because they believed this would ultimately lead to the triumph of their religious message despite the power of skeptical to downright hostile local audiences among the Sufi orders and non-Salafis dedicated to the Maliki juridical canon.

In the realm of politics, the subject of Chapter Six, Nigeria's Salafis base their political ideology on the core tenets of the Salafi creed and canon, tenets which cast Salafism as being not only the purest but the only true 
version of Islam, and require of Salafis to establish moral reform of a wayward Muslim society. Salafi scholars seek to bring about social, political, and religious reform, which collectively represent a "return" to the Prophet Muhammad's Islam, by speaking truth to power and advising and reprimanding, as necessary, Muslim political rulers. In navigating the multi-polar and complex realm of national and regional politics, Thurston argues, Nigerian Salafi scholars educated in Saudi Arabia unwittingly opened the door to cruder and more extreme, militant voices of figures lacking the same level of study of the Salafi canon or Sunni Islam generally. The most infamous of the latter is "Boko Haram," the jihadi-insurgent group today based around Lake Chad in Nigeria, Chad, and Niger, which calls itself Jama'at Ahl al-Sunna li-l-Da'wa wa-l-Jihad and is led by the bombastic Abubakar Shekau.

Boko Haram, under the leadership first of the revivalist preacher $\mathrm{Mu}$ hammad Yusuf and then Shekau, is covered at length in the book's third and final part, which is composed of two chapters. Yusuf, unlike mainstream Nigerian Salafis, sought to weaponize the Salafi canon against the state instead of using it as a tool to bring about desired reforms. Drawing on the writings of influential Arab jihadi ideologues including Abu Muhammad al-Maqdisi and the apocalyptic revolutionary Juhayman al-'Utaybi, the latter of whom participated in the 1979 seizure of the Grand Mosque in Mecca, Yusuf cited key Salafi concepts such as al-walä' min al-mu'minin wa-l-bara' 'an al-käfirin (loyalty to the Believers and disavowal of the Disbelievers) and beliefs about absolute monotheism (tawhìd) as the basis of his revivalist preaching. Based on these principle, he claimed, Muslims must not only fulfill their ritual duties such as prayer and fasting during Ramadan but also actively fight "unbelief" (kufr) and "apostasy" (ridda) and bring about God's rule on earth, following the correct path of the community of the Prophet Abraham (Millat Ibrähìm) referenced in multiple Quranic verses and outlined as a theological project for action by al-Maqdisi in a lengthy book of that name that has had a profound influence on the formation of modern Sunni jihadism.

Instead of seeing Boko Haram, particularly under Shekau's leadership, as a "Salafi" or "jihadi-Salaf" group, Thurston argues it is a case study of how a group that at one point in its history adhered to Salafism can move away from and beyond it. In the case of Shekau and his "post-Salafism," he writes, the group, like Islamic State, has shifted away from the Salafi canon and toward a jihadism that uses only stripped-down elements from the canon and does so solely to propagate a militaristic form of jihad. Even 
when referencing historical religious authorities such as Ibn Taymiyya, Thurston points out, Boko Haram and Islamic State leaders and members often do so through the lens of modern Sunni jihadi ideologues like Juhayman al-'Utaybi, al-Maqdisi, and Abu Musáb al-Zarqawi, figures who have come to form a Sunni jihadi canon of texts, intellectuals, and ideologues. Shekau, in short, has given up canonical Salafism and moved toward a more bombastic and scholastically more heterodox and less-Salafi-thanjihadi creed of political violence.

Thurston also pushes back against the often crude stereotyping of African Islamic traditions and movements that sees African Muslims as being defined by their "syncretic" mix of traditional African religious traditions and "orthodox" Islam, the latter usually a stand-in for "Arab" and "Middle Eastern" Islam. Islam and Islamic movements in Africa have developed in social and political environments that are not mirrors to the dominant models of the Arab world (in particular, Egypt). He convincingly points out that analysis of all forms of African Islamic social and political mobilization through a Middle East and Egypt-heavy lens obscures much more than it elucidates. The book includes useful glossaries of key individuals and Arabic terms referenced in the text as well as a translation of a sermon by the late, revered Salafi scholar Muhammad Nasir al-Din al-Albani that is part of the mainstream Salafi canon. Extensive in its coverage of the history, evolution, and sociopolitical and religious development of Salafism in Nigeria as well as the key role played by Saudi Salafi universities and religious institutions and quasi-state NGOs, the book expands the scholarly literature on Salafism, Islam in Africa, and political Islam and Islamic social movements. It also contributing to ongoing debates and discussions on approaches to the study of the role of texts and textual traditions in the formation of individual and communal religious identity.

Christopher Anzalone

Research Fellow, International Security Program Belfer Center for Science and International Affairs, Harvard University $\& \mathrm{PhD}$ candidate, Institute of Islamic Studies, McGill University 